\title{
Isolated tricuspid valve Libman-Sacks endocarditis in a patient with antiphospholipid antibody syndrome
}

\author{
Kunal Mahajan, ${ }^{1}$ Prakash Negi, ${ }^{1}$ Rajeev Merwaha, ${ }^{1}$ Meha Sharma ${ }^{2}$
}

\begin{abstract}
- Additional material is published online only. To view please visit the journal online (http://dx.doi.org/10.1136/ bcr-2017-219217).
\end{abstract}

'Department of Cardiology, Indira Gandhi Medical College, Shimla, Himachal Pradesh, India ${ }^{2}$ Department of Rheumatology, King George's Medical University, Lucknow, India

\section{Correspondence to} Dr Kunal Mahajan, kunalmahajan442@gmail.com

Accepted 8 August 2017

\section{DESCRIPTION}

A 30 year-old woman presented with an episode of transient ischaemic attack (TIA). She had a history of four consecutive first trimester abortions over the past 5 years and had no live issues. A physical examination revealed livedo reticularis on her palms and feet (figure 1). On cardiac auscultation, a pansystolic murmur was heard in the tricuspid area. The remainder of the physical examination was unremarkable. The patient denied any history of dyspnoea, palpitations or swelling of the feet. She had leucopenia and thrombocytopenia with a platelet count of $80 \times 10^{9} / \mathrm{L}$. Rheumatological evaluation yielded a positive lupus anticoagulant and elevated $\operatorname{IgG}$ anticardiolipin antibody levels $(>300 \mathrm{U} / \mathrm{mL})$. However, testing for antinuclear

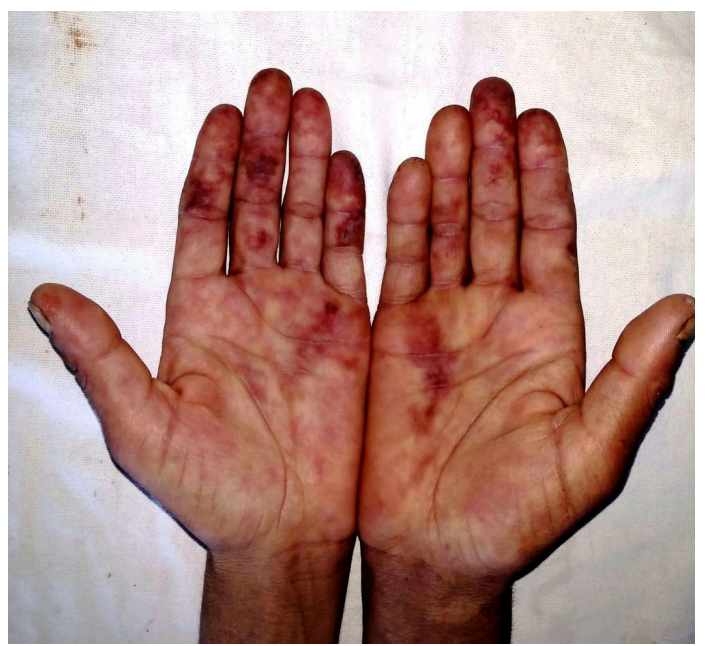

Figure 1 Bilateral palms showing reddish-cyanotic, reticular pattern of skin, characteristic of livedo reticularis.

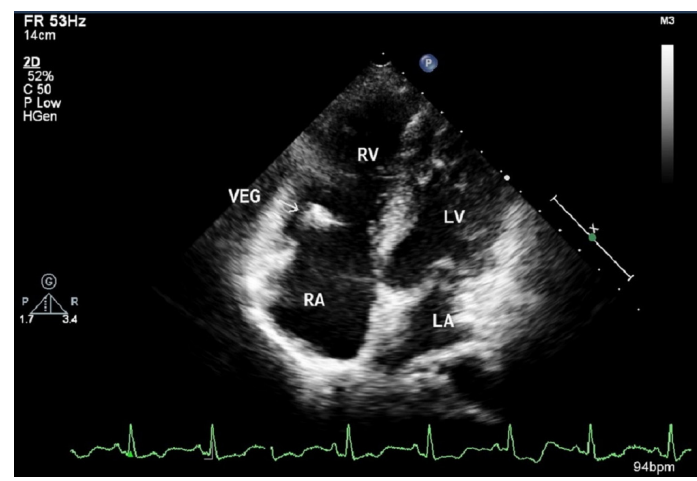

Figure 2 Echocardiogram, apical four-chamber view, showing a subtricuspid vegetation. $L A$, left atrium; LV, left ventricle; $R A$, right atrium; $R V$, right ventricle.

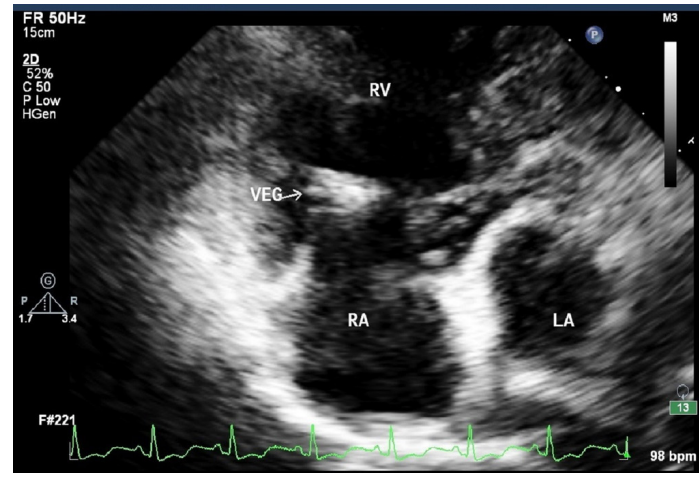

Figure 3 Echocardiogram-modified parasternal short axis view showing the heterogeneous echogenicity and irregular margins of the vegetation. LA, left atrium; RA, right atrium; $\mathrm{RV}$, right ventricle.

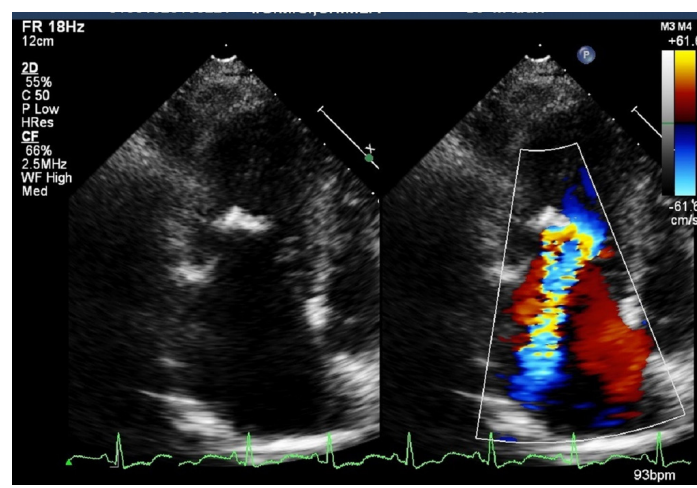

Figure 4 Echocardiogram with colour Doppler comparison showing the subtricuspid vegetation and evidence of moderate tricuspid regurgitation.

antibody and antibodies against IgM anticardiolipin and beta-2-glycoprotein 1 yielded negative results. Screening for secondary causes of positive antiphospholipid antibodies was unremarkable including a negative work-up for systemic lupus erythematosus (SLE). Brain imaging was also normal. Echocardiography was done that revealed mildly thickened tricuspid valve leaflets and a $6 \times 8 \mathrm{~mm}$ subtricuspid mass which was heterogeneous in echogenicity with irregular borders and showed no independent motion (figures 2 and 3, online supplementary video 1). These findings led to a diagnosis of Libman-Sacks endocarditis (LSE). On colour flow imaging, moderate tricuspid regurgitation was seen (figure 4). All the other valves were free of disease and ventricular function was normal. There was no evidence of any intracardiac shunt on echocardiography. Blood cultures, performed for a vast array of microorganisms including HACEK group, were 
sterile and C-reactive protein was normal. Patient was started on warfarin and aspirin and repeat antibody testing at 3 months confirmed the diagnosis of antiphospholipid antibody syndrome (APS), consistent with the presentation with TIA (suggesting arterial thrombosis) and livedo reticularis.

\section{Learning points}

- Libman-Sacks endocarditis (LSE) should be strongly suspected when any significant valve vegetation is identified in a patient with systemic lupus erythematosus and/or antiphospholipid antibody syndrome.

- LSE usually involves the mitral and aortic valves and isolated tricuspid valve involvement is extremely rare.

- LSE vegetations have a typical appearance on echocardiography characterised by irregular margins, heterogeneous echogenicity and no independent motion.

- LSE vegetations are typically small (1-4 $\mathrm{mm}$ ) and respond well to anticoagulants. In the present case, the large vegetation and poor response to treatment raise the speculation that these lesions undergo a progressive increase in size and severity, if left untreated for longer disease durations.

- Treatment involves drug treatment with steroids and anticoagulation, while surgery is reserved for worsening valvular damage and dysfunction.
At 6-month follow-up, there was no significant reduction in the size of the Libman-Sacks vegetation. However, there was no clinical deterioration, so conservative management was continued. LSE is a typical cardiac manifestation of autoimmune diseases like SLE and APS and usually involves the mitral and aortic valves. Tricuspid valve involvement is extremely rare. ${ }^{1}$ Conservative treatment with anticoagulation is the recommended treatment. Patients with severe intractable symptomatic valvular dysfunction require surgical intervention. ${ }^{2}$

Contributors $\mathrm{KM}$ and PN made the diagnosis and performed the complete investigations and were involved in the management of the patient. KM wrote the manuscript. RM performed the literature search. RM and MS corrected the manuscript and gave conceptual advice. All authors read and approved the final version of the manuscript.

Competing interests None declared.

Patient consent Obtained.

Provenance and peer review Not commissioned; externally peer reviewed.

(c) BMJ Publishing Group Ltd (unless otherwise stated in the text of the article) 2017. All rights reserved. No commercial use is permitted unless otherwise expressly granted.

\section{REFERENCES}

1 Moaref AR, Afifi S, Rezaian S, et al. Isolated tricuspid valve Libman-Sacks endocarditis and valvular stenosis: unusual manifestations of systemic lupus erythematosus. J Am Soc Echocardiogr 2010;23:341.e3-341.e5.

2 Bai Z, Hou J, Ren W, et al. Diagnosis and surgical treatment for isolated tricuspid Libman-Sacks endocarditis: a rare case report and literatures review. J Cardiothorac Surg 2015;10:93.

Copyright 2017 BMJ Publishing Group. All rights reserved. For permission to reuse any of this content visit

http://group.bmj.com/group/rights-licensing/permissions.

BMJ Case Report Fellows may re-use this article for personal use and teaching without any further permission.

Become a Fellow of BMJ Case Reports today and you can:

- Submit as many cases as you like

- Enjoy fast sympathetic peer review and rapid publication of accepted articles

- Access all the published articles

Re-use any of the published material for personal use and teaching without further permission

For information on Institutional Fellowships contact consortiasales@bmjgroup.com

Visit casereports.bmj.com for more articles like this and to become a Fellow 